\title{
Prosecutorial Discretion at the Special Court for Sierra Leone: A Critique
}

\author{
Ishmail Pamsm-Conteh ${ }^{1,2}$ \\ ${ }^{1}$ Faculty Member, University of Makeni, Makeni, Sierra Leone \\ ${ }^{2}$ Faculty Member, Ernest Bai Koroma University of Science and Technology, Makeni, Sierra Leone \\ Correspondence: Ishmail Pamsm-Conteh, Faculty Member, University of Makeni, Makeni, Sierra Leone. E-mail: \\ ipconteh@ebkustsl.edu.sl
}

Received: June 19, 2021

Accepted: July 29, 2021

Online Published: July 30, 2021

doi:10.5539/ilr.v10n1p249

URL: https://doi.org/10.5539/ilr.v10n1p249

\begin{abstract}
Principle 1 of the International Law Commission demands that any person who commits an act which constitutes a crime under international law is responsible and therefore liable to punishment. This is supported by various other international treaties, obligations, and also under customary international law. The mandate of the Special Court for Sierra Leone (The Special Court) rests with United Nations Security Council Resolution 1315(2000); to prosecute those who bear the greatest responsibility for serious international crimes committed during the country's civil war, which lasted from 1991-2002. To be clear, there were many protagonists in the conflict. However, the Special Court, which lasted between 2002 and 2012, prosecuted only thirteen members from selected groups, who were alleged to have committed such offences. Although there was considerable evidence to have supported additional prosecutions from the other warring factions in the conflict. As it was the responsibility of the Prosecutor to select those who were to be prosecuted; was the prosecutorial discretion robust enough in the case selection of those that were prosecuted, or was it a case of selective enforcement, or was it even discriminatory whilst trying to achieve the Court's mandate? This paper aims to evaluate the exercise of prosecutorial discretion at the Special Court, with a view to determining, whether the manner in which it was exercised may have led to the Prosecutor underachieving the Court's mandate.
\end{abstract}

Keywords: prosecutorial discretion, selective enforcement, insider witnesses, non-impunity and case selection

\section{Introduction}

The obligation to investigate and prosecute persons alleged to have committed crimes under international law, is now firmly established and it applies to both international and non-international conflicts. This obligation lies in the principle of non-impunity for offences committed during conflicts, which has its roots arguably in the first modern day international criminal trials held at Nuremberg, in 1945. Where it was held; "crimes against international law are committed by men, not by abstract entities, and only by punishing individuals who commit such crimes can the provisions of international law be enforced."

This position of prosecuting individuals who commit such crimes has been reflected during the conflicts, in the former Yugoslavia, Rwanda and in Sierra Leone. Where the United Nations(UN) established the International Criminal Tribunal for Yugoslavia (ICTY) in 1993, the International Criminal Court for Rwanda (ICTR) in 1994 and the Special Court for Sierra Leone in 2002, respectively. The establishment of the International Criminal Court (ICC) through the Rome Statute which came into force, on I July 2002, and various other internationalised ad hoc courts elsewhere in the world, are all geared towards these same goals. Which are primarily focused on holding individuals accountable by punishing such perpetrators, whilst such punishments should serve as deterrents, and also offering justice to the victims of such crimes.

Central to achieving this aim, is the responsibility of the Prosecutors at any international court or tribunal, which is to investigate and prosecute persons alleged to have committed crimes that fall under international law.

\footnotetext{
${ }^{1}$ Judge Philippe Kirsh, President of the International Criminal Court, Keynote Address at the Conference, 'Applying the Principles of Nuremberg at the ICC', "Judgement at Nuremberg." Held on the $60^{\text {th }}$ Anniversary of the Nuremberg Judgement. Washington University, $30^{\text {th }}$ September 2006 .p.3< https://www.icc-cpi.int/NR/rdonlyres/ED2F5177-9F9B-4D66-9386-5C5BF45D052C/146323/ PK_20060930_English. pdf. $>$ accessed 25 July 2021
} 
Nevertheless, he or she is not expected to prosecute everyone that is accused of such crimes. However, when the Prosecutor does his or her case selection, it should be based on guidelines surrounding the peculiarity of the conflict, and the gravity of the offences.

The paper discusses the principle of prosecutorial discretion. In doing so, it examines how it was applied at the ICTY, the ICTR, currently at the ICC and at the Special Court itself. This would be followed by explaining the mandate of the Special Court, which was to; "prosecute those who bear the greatest responsibility" for crimes committed during the country's civil war, as found within its temporal jurisdiction. It highlights selected alleged cases which were never prosecuted though there was prima facie evidence warranting prosecutions. It then analysis the principle of prosecutorial discretion alongside the mandate of the Special Court, before the paper concludes.

\section{The Concept of Prosecutorial Discretion}

The meaning of prosecutorial discretion is given as, "a prosecutor's power to choose from the options available in a criminal case, such as filing charges, prosecuting, not prosecuting, plea-bargain, and recommending a sentence to the Court." 2 Maria Varaki writes, "The concept of prosecutorial discretion is based largely on policy criteria, which are usually not defined in the statutes of the tribunals, leaving a huge gap of indeterminacy." 3 She continues, "This indeterminacy is what is called prosecutorial policy or strategy, and it should be founded on public prosecutorial guidelines that strengthen the legitimacy of the court and establishes transparency."4 Judge Daniel Ntanda Nsereko, writing on the same subject matter states:

The Prosecutor must identify what persons "bear the greatest responsibility for such violations." Once they have made these preliminary determinations then they 'shall prepare an indictment. This peremptory language suggests a duty and not a discretion on the part of the Prosecutor to indict. ${ }^{5}$

When the responsibility of the Prosecutor and the above statements are put into context, it lends credence to the fact that the Prosecutor has no discretion in the case selection for prosecution at international criminal courts. To support this assertion, the ICTY Statute held, "once the Prosecutor has initiated and concluded his investigation, the Statute vests authority in the Prosecutor to exercise his discretion and judgement as to whether an indictment should be filed." ${ }^{\prime 6}$ In this regard, the Prosecutor's discretion is to be exercised on the basis of his appreciation of the sufficiency of the evidence and the position of the accused."

On the issue of indictment of perpetrators, the considered guidelines in achieving this, must be discernible or clearly stated. For example, Carla Del Ponte, former Prosecutor at the ICTY and ICTR, shaped the indictment strategy of the Office of the Prosecutor (OTP) to focus on; gravity of the crimes and the level of responsibility of the alleged perpetrators. ${ }^{8}$ Carla's successor at the ICTR, Prosecutor Hassan Jallow, in reviewing the tribunal's case load, aimed his exercise of discretion on; "the chances of conviction rather than merely establishing a prima facie case." $"$

At the ICC, 'situations' are identified through one of the three modes or 'trigger mechanisms' set out in its Statute: Security Council referral (Article 13), State Party referral (Article 14) and Prosecutorial Initiative (Article 15). ${ }^{10}$ The former ICC Prosecutor, Luis Moreno Ocampo, said that in determining whether to exercise his proprio motu

\footnotetext{
2 Black's Law dictionary, ninth edition ( $p, 534)$

${ }^{3}$ Maria Varaki `Introducing a fairness-based theory of prosecutorial legitimacy before the International Criminal Court, `European Journal of International Law ${ }^{\prime}(2016$ )p. $3<\mathrm{http}: / /$ www.ejil.org/article.php?article=2667\&issue=132> accessed 10 June 2021

${ }^{4}$ Ibid

${ }^{5}$ Daniel Ntanda Nsereko, 'Prosecutorial Discretion before National Courts and International Tribunals 'Journal of International Criminal Law J Int Criminal Justice;3(2005) 124-144, p.3<https://academic.oup.com/jicj/article-abstract/3/1/124/888679/Prosecutorial-Discretion-beforeNational-Courts?redirectedFrom=fulltext $>$ accessed 12 June 2021

${ }^{6}$ ICTY Article 17, para 4.

${ }^{7}$ Hassan Jallow 'Prosecutorial Discretion and International Criminal Justice', Journal of International Criminal Justice J Int Criminal Justice (2005) 3 (1): 1451 (March 2005 ) p. 2.<https://academic.oup.com/jicj/article-abstract/3/1/145/888729/Prosecutorial-Discretion-andInternational?redirectedFrom $=$ fulltext $>$ accessed 7 June 2021

${ }^{8}$ Klaus Bachmann and Aleksandra Fatic, ' The UN International Criminal Tribunals Transition Without Justice' (First Published 2005, Routledge,) p. 89

${ }_{9}$ Jallow (n 7)p. 6

${ }^{10}$ Rome Statute of the International Criminal Court, Articles, 13, 14 and $15<\mathrm{http}: / /$ legal.un.org/icc/statute/99_corr/cstatute.htm $>$ accessed 5 June 2021
} 
powers, he is required to consider three factors, all of them rooted in provisions of the ICC Statute. ${ }^{11}$ First, to determine whether the available information provides a reasonable basis to believe that a crime within the jurisdiction of the Court has been or is being committed. Second, to assess whether the case would be admissible in terms of Article 17 of the ICC Statute. ${ }^{12}$ This involves examining the standard of whether the national courts are unwilling or unable genuinely to proceed with prosecution, (the principle of complementarity). And it also involves evaluating the 'gravity' of the offence. ${ }^{13}$ If these conditions are met, the prosecutor must then give consideration to 'interests of justice' requirement. ${ }^{14}$ Third, arrest warrants or summons to appear are prepared only when a case is nearly trial-ready in order to facilitate the expeditiousness of the judicial proceedings. ${ }^{15}$

At the Special Court, it was solely the Prosecutor's responsibility to select those who should be investigated and prosecuted, as provided for, under Article 15(1) of its Statute. Which reads: "The Prosecutor shall be responsible for the investigation and prosecution of persons who bear the greatest responsibility for serious violations of international humanitarian law and crimes under Sierra Leonean law committed in the territory of Sierra Leone since 30 November 1996." 16

The Special Court had different Prosecutors at various stages of its judicial activities. David Crane (the first and only prosecutor at the Court to have issued indictment), broadly outlined his prosecutorial strategy. However, he was not specific about the guidelines or how he meant to exercise his prosecutorial discretion, as established by good practice at the earlier international tribunals. ${ }^{17}$ Specifically, the ICTY and ICTR. Nonetheless, he did state:

[T] he standard for international prosecutions should be "greatest responsibility". That is the clear standard I was given to prosecute these warlords. If that phrase in the mandate of "greatest responsibility" was not included in the agreement, this hybrid international war crimes tribunal would not exist." 18

This was the closest Prosecutor Crane came to explaining his prosecutorial discretion in terms of case selection. His successor, Stephen Rapp, (who did not prosecute anyone), writing in Charles Jalloh's edited book, commented:

[W] hen there were innocents killed on all sides, there is natural pressure for prosecutions on all sides. Yet in doing so, one should not ignore the questions of gravity and scale, and whether the crimes were part of a widespread pattern of conduct. ${ }^{19}$

Prosecutor Rapp's comment on prosecuting all sides to the conflict bears particular relevance. As a matter of fact, the issue of the Prosecutor's discretion came before the Trial Chamber in the case of Prosecutor v. Norman, Fofana, Kondewa. ${ }^{20}$ This was with regards to, 'leave to file an Interlocutory Appeal in the amendment of an indictment,' to include sexual offences at the CDF Trials. In refusing the appeal, the Appeals Chamber held:

By contending that the Office of the Prosecutor is obliged to prosecute "to the full extent of the law" is the Prosecution implying that it is obliged to prosecute all crimes for which there may be supporting evidence... [0] $n$ what grounds or principles, should the prosecutorial duty to prosecute to" the full extent of the law" be limited in application to the range of alleged criminality involved but not the range of the alleged perpetrator? In our opinion, the overall interest of justice is not served by such limitations or differentiation of the prosecutorial discretion. ${ }^{21}$

The interpretation of that Judgement could well be that the Prosecutor cannot prosecute all those individuals who

\footnotetext{
${ }^{11}$ William A. Schabas, Prosecutorial Discretion v. Judicial Activism at the International Criminal Court, Journal of International Criminal Justice J. Int crim Justice ( published November 2008) https://academic.oup.com/jicj/article-abstract/6/4/731/899128).p 4, accessed 18 June 2021

${ }^{12}$ Rome Statute of the International Criminal Court, $<$ https://www.icc-cpi.int/resource-library/documents/rs-eng.pdf $>$ accessed 23 June 2021

${ }^{13}$ Ibid

${ }^{14}$ Luis Moreno-Ocampo, The Office pf the Prosecutor, Prosecutorial Strategy, 14 September 2006. The Hague, pp 4-5 <https://www.icccpi.int/NR/rdonlyres/D673DD8C-D427-4547-BC69-2D363E07274B/143708/ProsecutorialStrategy20060914_English.pdf> accessed 23 June 2021

${ }^{15}$ Ibid

${ }^{16}$ Statute of the Special Court for Sierra Leone. http://www.rscsl.org/Documents/scsl-statute.pdf, accessed 16 June 2021.

${ }^{17}$ David M, Crane 'Dancing with the Devil: Prosecuting West Africa's War Lords: Building Initial Prosecutorial Strategy for an International tribunal after Third World Armed Conflicts'. Case Western Reserve Journal of International Law Vol 37, Issue 1, 2005, p. 5 $<$ http://scholarlycommons.law.case.edu/cgi/viewcontent.cgi?article=1355\&context=jil $>$ accessed 1 June 2021

18 ( N 17) supra

${ }^{19}$ Charles Chernor Jalloh `The Sierra Leone Special Court and its Legacy, The Impact for Africa and International Criminal Law` (First Paperback Edition Published in 2015,Cambridge University Press) p.27

${ }^{20}$ Prosecutor v. Norman, Fofana and Kondewa (“C.D.F. Case) Case No.04-14-T, 2 August 2004

${ }^{21}$ Ibid at para 30
} 
committed alleged crimes, during the conflict. Which supports the UN Sectary-General's view, that the persons to be prosecuted before the Court should be limited, but the choice should not be selective or discriminatory. ${ }^{22}$ Nonetheless, it is submitted that, if the crimes came under the primary jurisdiction of the Court, it should have been the main focus of the Prosecutor.

However, as this paper would show, it would appear that, the Court was selective in its case selection based on the fact that it prosecuted only members of the CDF, RUF, AFRC and former President Charles Taylor of Liberia. Whilst it did not prosecute members of the Sierra Leone Army, (SLA), the Sierra Leone Police,(SLP), and other non-state actors who committed offences which fell within scope of the primary jurisdiction of the Court.

Additionally, even in the cases of those that were prosecuted, the Prosecutor may again have been discriminatory in his decision, as some leaders who were more senior in the command structure of the various armed factions were not prosecuted. At the same time, some of those very leaders even worked with the prosecution to testify against their subordinates in the leadership chain of command. A position which departs from the established practice at the earlier international tribunals already mentioned, where subordinates working with the prosecution testified against their leaders for a reduced sentence. This issue of leaders being used as insider witnesses by the Court is further discussed below.

\section{Interpreting the Phrase of, "Those Who Bear the Greatest Responsibility" as the Mandate of the Special Court}

The Agreement between the UN and the Government of Sierra Leone, (the Agreement) under Article 1(1) states; "There is hereby established a Special Court for Sierra Leone to prosecute "persons who bear the greatest responsibility," for serious violations of international law and Sierra Leonean law ..." During the negotiations leading to establishing the Special Court, between the UN Security Council and the UN Secretary General, the latter recommended extending jurisdiction to, ' those most responsible' including those in 'political or military leadership' roles, both, a 'leadership or authority position'. ${ }^{23}$ The former however, rejected jurisdiction over, 'those most responsible', preferring, ' those who bear the greatest responsibility' threshold, but stated, 'it should not limit jurisdiction to political and military leaders only. ${ }^{24}$ This preference was evidently that the leadership role or command authority of a suspect should be the principal criterion for the application of the greatest responsibility formulation. ${ }^{25}$ The Sectary-General accepted, the Security Council's, "persons who bear the greatest responsibility," threshold. However, he added that, it did not limit jurisdiction to political and military leaders only instead, the determination of the phrase' falls initially to the prosecutor and ultimately to the Court itself. ${ }^{26}$

According, to David Crane the Court's first Prosecutor, he interpreted, those persons whom he thought fell under the Court's mandate, in this way: ${ }^{27}$

These actors include gun runners, diamond dealers, the Russian and Ukrainian mafia, other international criminal organizations, and terrorists, to include Hezbollah and Al Qaeda. All of them were involved in West Africa taking blood diamond from the mines of eastern Sierra Leone and trading them for cash to buy weapons to sustain the conflicts throughout the region or international terrorism. ${ }^{28}$

The above statement seems to suggest that Prosecutor Crane, was to indict different categories of individuals whom he thought fell under the competence of the Court, in consonance with the UN Security Council and Secretary General's position. To support this premise one should again recall, what Prosecutor Crane had stated before the indictments were made public; "[T] he numbers of individuals that we now considered to indict went from 30,000 to around 20." ${ }^{29}$ However, what he did not explain was, how the numbers were whittle down from the former to the latter? Nor was the criteria which was employed, was it leadership or military roles, scale, or gravity of the offence? In the absence of such explanation, therefore, there was no discernible parameter to support his case

\footnotetext{
${ }^{22}$ UN Doc. S/2000/915, 4 OCT $2002<$ https://digitallibrary.un.org/record/424039 > p. 2 accessed 15 June 2021

${ }^{23}$ Kirsten Ainley, Rebecca Friedman and Chris Mahony, `Evaluating Transitional Justice (First Published 2015, Palgrave Macmillan) p. 87

${ }^{24}$ UN Letter Dated 22 December 2000 from the President of the Security Council addressed to the Sectary General, S/2000/1234< https://documents-dds-ny.un.org/doc/UNDOC/GEN/N01/455/50/PDF/N0145550.pdf > accessed 15 June 2021

${ }^{25} \mathrm{Ibid}$

${ }^{26}$ UN, Letter dated 12 January 2001 from the Sectary-General addressed to the President of the Security Council, S/2001/40< https://digitallibrary.un.org/record/424039> accessed 16 June 2021

${ }^{27}$ David M. Crane 'Dancing With the Devil: Prosecuting West Africa's Warlords: Building Initial Prosecutorial Strategy for an International Tribunal after Third World Armed Conflicts, 'Case Western Reserve Journal of International Law' Vol 37/Issue 1, 2005. p.2< http://scholarlycommons.law.case.edu/jil/vol37/iss1/1/> accessed 19 June 2021

${ }^{28}$ (N 27) supra

${ }^{29}$ Ibid
} 
selection, which should have legitimised his decision.

To that end, it should be noted that dozens of people were expected to be prosecuted, considering President Kabba's request in establishing the Court, which states: "The mandate of the court could be designed to be narrow in order to prosecute the most responsible violators and the leadership of the Revolutionary United Front. This could result in the numbers being limited to the dozens. ${ }^{" 30}$ However, only 13 persons were indicted during the Court's entire trials of ten years.

With the limited prosecutions, and putting President's Kabba's statement into context together with Prosecutor Cranes's ambition, it is therefore understandable that academic scholars like Chacha Murungu and Japhet Biegon who in commenting on the Prosecutor's interpretation of the phrase, "those who bear the greatest responsibility," had this to say: "... it has been argued that the definition adopted by the Prosecutor was too narrow and targets only a few culprits." ${ }^{11}$ The statement went on, "It only targets those who 'caused' or 'instigated' the war in Sierra Leone... It leaves out the possibility of other persons equally responsible for fuelling the war, or those that took part in the actual commission of international crimes in Sierra Leone." 32

As the Sectary General's view of the phrase was for the Prosecutor and the Court to determine, the matter of interpretation came before Trial Chamber I, by way of a Defence motion on the Court's lack of personal jurisdiction, under Article 1(1) in the CDF trial of Prosecutor v. Fofana. ${ }^{33}$ Fofana's defence counsel submitted that the Court did not have a personal jurisdiction over Fofana because the suspect fell outside the category of persons who bore" the greatest responsibility" for alleged serious international humanitarian law violations contained in his indictment. ${ }^{34}$ The Chamber held:

While those 'most responsible' obviously include the political or military leadership, others in command authority down the chain of command may also be regarded as ' most responsible' judging by the severity of the crime or its massive scale... ${ }^{35}$

The issue of interpretation of the phrase came to the fore yet again at the AFRC Trial, in Prosecutor $v$ Brima. ${ }^{36}$ Where it was contested that the references in Articles 1(1) and 15 of the Statute; "persons who bear the greatest responsibility" was a 'limitation on the Court's jurisdiction as to which persons may or may not be prosecuted and creates an evidentiary burden to be satisfied by the Prosecution. ${ }^{37}$ According to the Defence, the Prosecutor had not discharged his burden because witnesses showed that other prominent military leaders higher in rank, not their accused clients who were only lower ranked non-commissioned officers, bore the greatest responsibility for the heinous offences perpetrated in Sierra Leone. ${ }^{38}$ The Court ruled:

$[\mathrm{T}]$ he concept of greatest responsibility does not serve as a distinct jurisdictional threshold or limitation. Instead, it "solely purports to streamline the focus of prosecutorial strategy. In particular, taking into account the relevant documentary history, this group of judges rejected the idea that the drafters of the Statute of the SCSL could have intended "greatest responsibility" to serve as a dispositive jurisdictional threshold which, if unmet, would require them to dismiss a case. ${ }^{39}$

It may appear that both Trial Chambers had given similar interpretations to the meaning of the phrase, that is; the phrase was meant to streamline or guide the prosecutor in considering who was to be prosecuted.

The matter came for clarity once again, before the Appeals Chamber by way of Prosecutor $v$ Kanu, ${ }^{40}$ who was appealing his conviction, arguing that the Trial Judges had misinterpreted and misapplied the applicable personal jurisdiction threshold. ${ }^{41}$ The Appeals Chamber ruled:

\footnotetext{
${ }^{30}$ President of the Republic of Sierra Leone, Annex to the letter dated 12 June 2000, addressed to the President of the Security Council, U.N. Doc. S/2000/786/ < http://www.rscsl.org/Documents/Establishment/S-2000-786.pdf > accessed 3 June 2021

${ }^{31}$ Chacha Murungu and Japhet Biegon, `Prosecuting International Crimes in Africa`(Pretoria University Law Press 2011) p.102

${ }^{32}$ Ibid

${ }^{33}$ Prosecutor v. Fofana, Case No. SCSL-04-14-PT (Preliminary Defence Motion),3 March 2004

${ }^{34}$ ( N33) at para 21

${ }^{35}$ Ibid at para 22

${ }^{36}$ Prosecutor v. Brima,Case No. SCSL-04-16-T, Joint Legal Part Defence Motion for Judgement of Acquittal Under Rule 98. 13 December 2005, paras. 1-2

${ }^{37}$ Ibid

${ }^{38}$ Ibid at para. 28

${ }^{39}$ Prosecutor v Brima, Case No SCSL-04-16-T, Trial Judgement, 20 June 2007, para. 653

${ }^{40}$ Prosecutor v Kanu Case No SCSL 03-13-T, Decision on Defence Motion for Judgement of Acquittal Pursuant to Rule 98, 31 March 2006

${ }^{41}$ Ibid
} 
It is evident that it is the Prosecutor who has the responsibility and competence to determine who are to be prosecuted as a result of investigation undertaken by him. It is the Chambers that have the competence to try such persons who the Prosecutor has consequently brought before it as persons who bear the greatest responsibility. ${ }^{42}$

The interpretation of this ruling was, "who bears the greatest responsibility" should be decided by the Prosecutor alone, during his investigations. Whilst the Judges' sole function was, to adjudicate upon the individuals that were brought before them during trial. ${ }^{43}$ In other words, the responsibility of the Prosecutor was unlike that of the Judges, insofar as application of the phrase was concerned.

Based on the foregoing, it can be said, that the personal jurisdiction, of "those who bear the greatest responsibility" was aimed at the leadership, command structure, the scale and the gravity of the crimes committed during the conflict. Reinforcing the UN's position. ${ }^{44}$

Though Prosecutor Crane, indicted thirteen persons, the Court only successfully convicted nine persons. ${ }^{45}$ In the context that the war was described as one of the most brutal in the present generation and lasting for eleven years, could this number be said to be reflective of," those who bear the greatest responsibility," mandate of the Court? This paper continues to explore further, if it was or if it was not the case.

\section{Documented Incidents Which may Fallen within the Scope of, "those who bear the Greatest Responsibility" Threshold; for Which There Were no Prosecutions}

This part of the paper shines a torch on some of the documented incidents where alleged crimes were committed which fell within the Court's mandate, which were never prosecuted.

1) UN Security Council Resolution 1370 (2001), Expresses its continued deep concern at the reports of human rights abuses and attacks committed by the RUF, the Civil Defence Forces (CDF) and other armed groups and individuals, against the civilian population, in particular the widespread violation of the human rights of women and children, including sexual violence, demands that these acts cease immediately, and requests the Secretary- General to ensure that all human rights monitoring positions within UNAMSIL are filled in order to address the concerns. ${ }^{46}$

2) UN Security Council Resolution 1346 ( 2001) again reiterates, its deep concern at the reports of human rights abuses committed by the Revolutionary United Front (RUF) and others, including other military groups, against the civilian population, in particular the harassment and forced recruitment of adults and children for fighting and forced labour, demands that these acts cease immediately, and requests the Secretary-General to ensure all human rights monitoring positions within UNAMSIL are filled in order to address the concerns raised in paragraphs 44 to 51 of the report of the Secretary-General. ${ }^{47}$

3) According to the findings of the Sierra Leone Truth and Reconciliation Commission (TRC), the Sierra Leone Army (SLA) was responsible for the third largest number of violations during the same period. Some $6.8 \%(2,724$ out of 40,242$)$ of the allegations made in the statements were levelled at the SLA. ${ }^{48}$ Soldiers of the SLA undertook retaliatory actions, including summary killings, against members of the civilian population, whom they suspected of having assisted or supported the insurgents. On occasions, they did so with undue abandon or inappropriate feelings of vengeance against persons they perceived to be "rebels" or "collaborators". Many soldiers were driven to such acts by an urge to avenge the deaths of fallen comrades at the hands of the insurgent. ${ }^{49}$

From the forgoing, it seemed such incidents from very credible sources, such as the UN itself, and the country's own TRC findings which found that such cases fell within the court's interpretation of "those who bear the greatest" responsibility threshold, were unfortunately not prosecuted.

\footnotetext{
${ }^{42}$ Prosecutor v. Brima, Case No SCSL-04-16-T, Appeals judgement, 22 February 2008, para.281

${ }^{43}$ Jalloh (n 19) pp. 610-611

44 (N 24-25) Supra

${ }^{45}$ The Residual Special Court for Sierra Leone. Website http://www.rscsl.org/CDF.html accessed 25 July2021. Two individuals died before they could be prosecuted, (RUF's Foday Sankoh and Sam Bockarie) one individual died during the trial, (CDF's Sam Hinga Norman), and another individual's whereabouts remain unknown (AFRC's Johnny Paul Koroma)

${ }^{46}$ UN Security Council Resolution 1370 (2001) at para 4, adopted by the Security Council at its 4374th meeting, on 18 September 2001

${ }^{47}$ ( N 46) supra

${ }^{48}$ Sierra Leone TRC Report Volume 2 Chapter 2, at para 109

${ }^{49}$ Ibid
} 
Whilst it is recognised that the UN Peacekeepers were to be prosecuted by the sending states, it was still possible though, for them to have been prosecuted by the Special Court, if the conditions attached to their prosecutions were met. $^{50}$

\section{Analysis of the Concept of Prosecutorial Discretion Alongside the Court's Mandate of Prosecuting, "Those Who Bear the Greatest Responsibility"}

Questions have been asked elsewhere regarding the Prosecutor's case selection at the Court, even within the groups that were prosecuted. Prosecutor Brenda Hollis in her response to the specific question on why President Kabba, the leader of the CDF, was not indicted, unlike his deputy, Sam Hinga -Norman who was indicted? She responded in this way; "The evidence supported the indictment against Hinga-Norman; it supported his responsibility for international crimes committed by the CDF... our evidence simply did not support an indictment against Kabba, so we did not indict him." ${ }^{51}$

On the contrary, the TRC finding regarding President Kabba's role was:

The Commission finds that the War Council and the President were fully and timeously apprised of events that were taking place on the ground in Sierra Leone during their period in exile. They did not act to stop the violations being carried out by CDF elements nor did they speak out against them. As such, they are held responsible for the acts of their agents on the ground. ${ }^{52}$

If Prosecutor Rapp's statement is to be relied upon, both the TRC and the Special Court, were privy to the same source of information, insofar as the information regarding President Kabba was concerned. ${ }^{53}$ He states, "If you study the report of the TRC, you can see an accounting of the reported violations attributed to the various armed groups. This was published after the SCSL prosecution began its work but was similar to the information that was within the Prosecutor's possession." ${ }^{54}$

That being the case, the TRC and UN Security Council Resolutions, arrived at the same conclusion that; (all sides committed similar offences of human right violations which fell within the mandate of the Court). So was this a missed opportunity for the Court? In essence, by failing to prosecute members of the other armed groups such as the SLA and the SLP, one inference to be drawn from this, is that Court's mandate may have been underachieved.

It is again important to cite Prosecutor Rapp:

I did have investigators who then recommended to me that we prosecute at least one additional person. I weighed that question for some time, but declined to proceed on practical grounds because of the difficulties and the time necessary to make an arrest, and the limitation of the Court's resources that made it impossible to ensure, if we pursued that case, that we would complete it. ${ }^{55}$

It should be noted that whilst Prosecutor Hollis offered the reason for declining to prosecute as lack of evidence, ${ }^{56}$ Prosecutor Rapp on the other hand, offered the reasons of practical difficulties, and limitation of resources amongst others. It would therefore appear that both Prosecutors had different reasons for not prosecuting perpetrators. Therefore, if Prosecutor Rapp's reasoning was not for want of evidence, his reason cannot justify the nonprosecution of the one person, he was referring to. Bearing in mind that, once there is prima facie evidence supporting prosecution, the Prosecutor no longer has a discretion, but a duty to prosecute.

It might well have been that there was reluctance on the part of the Prosecutors to investigate some cases, as this Human Rights report suggests, "Special Court staff were resistant to interpreting the court's mandate to include regional or mid-level commanders who distinguished themselves by their brutality, citing time and resource constraints..." ${ }^{7}$ The report continued, "we also suggest that sufficient evidence to prosecute them would have been obtained in the process of building cases against top commanders who have already been indicted." ${ }^{158}$ It

\footnotetext{
${ }^{50}$ Articles 1 (2 ) and ( 3) of the Statute of the Special Court for Sierra Leone. http://www.rscsl.org/Documents/scsl-statute.pdf accessed 18 June 2021

${ }^{51}$ (N 24) supra. pp.91-92

${ }^{52}$ (N 48), supra, chapter 2, volume 2, at para 278

${ }^{53}$ (N 19) supra

${ }^{54}$ Ibid, p. 26

${ }^{55}$ Ibid, p. 25

${ }^{56} \mathrm{Ibid}$

${ }^{57}$ Human Rights Watch. Bringing Justice: The Special Court for Sierra Leone Accomplishments, Shortcomings, and Needed Support. (September 2004), Vol.16, No. 8(A), p. 6 https://www.hrw.org/sites/default/files/reports/sierraleone0904.pdf accessed 29 May 2019

58 ( N 29)supra
} 
might appear that this suggestion to the Prosecutors was not heeded. And if according to Prosecutor Hollis, "we go where the evidence took us" position is scrutinised, the only conclusion to be drawn, is that her statement was mere rhetoric.

Referring to this very Human Rights report, even if the perpetrators were not top commanders, but in the context of the personal jurisdiction of the Court, which was not only limited to leaders, it was also extended to individuals. Who were deemed to have bore the greatest responsibility of the crimes that were committed which offended against international law.

It would therefore appear that the Court declined to follow up on leads which might have provided evidence required for prosecution. ${ }^{59}$ As Judge Nsereko, quoted above held, "as long as a primary determination based on sufficiency of evidence, seriousness of the offence, individuals identified, then the Prosecutor no longer has a discretion, but a duty to prosecute." 60 As this duty was not fulfilled, it casts doubt on the exercise of the prosecutorial discretion at the court, in the author's view.

One of the most controversial exercise of prosecutorial discretion was the engaging of leaders as insider witnesses, without prosecuting those same leaders-a matter already raised above. Former Prosecutor at the ICTY and ICTR, Carla Del Ponte, explains the meaning of "insider witnesses" as, "persons in a position to provide crucial, high grade information about political and military decision making, because they had witnessed events at close proximity to the decision makers." 61 Similarly in the RUF Trial Chamber, ${ }^{62}$ it ruled:

These insider witnesses were themselves high ranking officers in the RUF or AFRC. Many of these witnesses were key participants to the crimes alleged in the Indictment and may be considered to be coperpetrators or accomplices. The Chamber reiterates that the Appeals Chamber has clarified that such persons may be considered accomplices even if they have not been charged with any criminal offences. ${ }^{63}$

This ruling once again, questions the exercise of prosecutorial discretion, in which the leaders who should have been prosecuted as accomplices, instead served as insider witnesses, eventually evading prosecution. One of such insider witnesses Gibril Massaquoi is currently standing trial in Finland where he and he his family were relocated after testifying at the Special Court on behalf of the prosecutor. He stands accused of committing war crimes and crimes against humanity in neighbouring Liberia during that country's civil war.

It is these circumstances which questions the prosecutorial discretion or prosecutorial strategy as to whether it was robust enough to have achieved the mandate of the Court? It is important to once more reflect on Prosecutor Rapp's statement: "prosecuting all sides may not be appropriate." 64 Additionally, it has to be emphasised that even if a strict mandatory prosecution is called for, there are no mechanisms of factual discretion since no criminal justice system has the capacity to prosecute all offences no matter how serious. ${ }^{65}$ The question is therefore not whether selective prosecution should occur, as it is essentially impossible that it does not, but when is selective enforcement unacceptable? ${ }^{66}$

Selectivity according to Kenneth Kulp Davies, means, "when an enforcement agency or officer has discretionary power to do nothing about a case in which enforcement would be clearly justified, the result is selective enforcement." 67 Would it be correct to infer that the case selection of the Prosecutor was selective and hence, discriminatory? This paper answers the question in the affirmative, based on the foregoing. Consequently, this offended against the UN Secretary-General's position cited above, at the time the Court was being established. ${ }^{68}$

It has also been argued elsewhere that the voluntary funding arrangement of the Court was responsible for the limited number of persons indicted. However, Article 6 of "the Agreement" states, "should voluntary contributions be insufficient for the Court to implement its mandate, the Sectary-General and the Security Council shall explore

\footnotetext{
59 Ibid

${ }^{60}$ ( N 5) supra

${ }^{61}$ Carla Del Ponte with Chuck Sudetic, 'Madame Prosecutor Confrontations with Humanity's Worst Criminals and the Culture of Impunity (Published 2008, Other Press New York) p. 128

${ }^{62}$ RUF Judgement SCSL-04-15-T, 2 March 2009

63 ( N 62) at para. 539

64 ( N 19) supra

${ }^{65}$ Kai Ambos and Andrew Sanders(eds), The Prosecutor of a Permanent International Criminal Court' (Freiburg: edn, iuscrim,2000) p. 525

${ }^{66}$ Kenneth Davies`Discretionary Justice: A Preliminary Enquiry (Baton Rouge; Louisiana State University Press 1969) pp 167-168

${ }^{67}$ Robert Cryer, Darryl Robinson and Sergey Vasiliev, 'An Introduction to International Criminal law and Procedure ( Fourth Edition 2009 Cambridge University Press) p. 193

68 (N 22) supra
} 
alternate means of financing the Special Court." ${ }^{, 69}$ To support this arrangement, there were instances in which the Court was supplemented by funds from the UN. ${ }^{70}$ This statement below is an example of such an occasion:

The Committee members engaged Member States in the UN Security Council and UN General Assembly in order to seek support for the subvention grant. As a result, the UN approved a subvention of USD $9,066,400$ for 2012. The subvention was granted to the Special Court on the condition that fundraising efforts are intensified. ${ }^{71}$

It would therefore appear that there is little evidence supporting the suggestions that the funding arrangement might have impinged on the number of individuals prosecuted. Even though the voluntary funding arrangement was challenging, it was highly unlikely that, the trials would have been halted for lack of funding. It is hereby offered that the worst-case scenario would have been for the UN to adopt an approach similar to that at the ICTY; where due to the length of time the trials were taking and the tribunal's running cost, in August 2003, the UN Security Council passed UN Security Council Resolution 1503 (2003). It urged the ICTY to, "concentrate on the prosecution and trial of the most senior leaders suspected of being most responsible for crimes within the ICTY's jurisdiction and to transferring cases involving those who may not bear this level of responsibility to competent national jurisdictions." ${ }^{2}$

\section{Conclusion}

Prosecuting individuals for crimes committed during conflict is a principle that is well entrenched in various international legal documents. The decision of prosecuting perpetrators at international criminal courts is exercised through the concept of prosecutorial discretion. In which guidelines such as, gravity, scale, leadership, sufficiency of evidence, amongst others are the usual criteria for selecting those to be prosecuted or not to be prosecuted.

The mandate of the Special Court for Sierra Leone rests with United Nations Security Council Resolution 1315(2000), which in part reads, “... to prosecute those persons who bear the greatest responsibilities for serious violations of international and Sierra Leone laws, committed in the territory of Sierra Leone." The fulfilment of this responsibility partly lies with the Prosecutor whose obligation was to investigate and prosecute those individuals who were deemed to have committed crimes during the conflict that fell within the Special Court's mandate.

Accordingly, there was prima facia evidence primarily from UN sources and the country's TRC findings that would seem to suggest that all sides to the conflict committed offences, which fell within the mandate of the Special Court. These core crimes, under international law were of a serious nature and individuals were identified not only by the TRC findings but also by the Special Court's own judgement. It should be remembered that the main protagonists in the war were members of the RUF rebels, the AFRC, CDF members, Charles Taylor, (former president of Liberia), members of the SLA, SLP and the International Peace keeping forces. However, only selected members of some groups were prosecuted, and even within those selected groups leaders and individuals who should have been indicted under the mandate of the Special Court, escaped prosecution. Hence, were not held accountable for their crimes.

Whilst Prosecutors at other international tribunals like the ICTY and ICTR had outlined their guidelines on case selection, the Prosecutor at the Special Court, did not, though he broadly outlined his strategy. On close scrutiny of those individuals that were prosecuted, no discernible guidelines could be identified as part of the prosecutorial strategy, which then raises the question whether the case selection was based on selective enforcement? It is therefore submitted that the Prosecutor, by not being able to outline his prosecutorial strategy, this questions the transparency and legitimacy of the case selection decision.

Though it is an agreeable fact that, the Special Court would not have been in the position to prosecute all those persons who had committed crimes during the conflict. But this paper disagrees that, individuals whose crimes were serious enough to fall within the Court's mandate, should not have been punished, for whatever reasons that were advanced by the Prosecutors.

The argument that the funding arrangement at the Court may have been responsible for the limited prosecutions cannot be sustained. This is because though it was voluntary by nature, the UN had made commitment that, where

\footnotetext{
${ }^{69}$ Ibid

${ }^{70}$ Residual Special Court for Sierra Leone website, under the heading documents; $<\mathrm{http}: / /$ www.rscsl.org/Documents/AnRpt10.pdf $>$ accessed 11 June 2021

${ }^{71}$ Ibid

72 UN Docs/ S/RES/1503/2003, On the Completion Strategy of the ICTY and ICTR, 28 August 2003 $<$ http://www.refworld.org/docid/3f535ca64.html > accessed 14 June 2021
} 
there was a shortfall of funding, this would be met by the UN itself. And there was evidence offered by this paper that, this commitment was met.

Based on the foregoing, the paper would conclude that, the exercise of prosecutorial discretion at the Court, may have culminated to the Court's under achieving its mandate of prosecuting, "those who bear the greatest responsibility" under UN Security Council Resolution 1315(2000).

\section{Copyrights}

Copyright for this article is retained by the author(s), with first publication rights granted to the journal.

This is an open-access article distributed under the terms and conditions of the Creative Commons Attribution license (http://creativecommons.org/licenses/by/4.0/). 